\title{
Feeding Method
}

National Cancer Institute

\section{Source}

National Cancer Institute. Feeding Method. NCI Thesaurus. Code C81267.

A description of the technique for the manner in which a subject is administered food. 